\title{
Seasonal variations in physico-chemical characteristics of River Yamuna in Haryana and its ecological best-designated use
}

KHAIWAL RAVINDRA*, AMEENA, MEENAKSHI, MONICA, RANI AND A. KAUSHIK

\section{Department of Environmental Sciences and Engineering, Guru Jambheshwar University, Hisar-125001 (India)}

\begin{abstract}
Various physico- chemical characteristics of river Yamuna flowing in Haryana through Delhi were studied in summer (April, 1998) and winter (Jan. -Feb., 1999). Ecological parameters like dissolved oxygen (DO), $\mathrm{pH}$, nitrate $\left(\mathrm{NO}_{3}{ }^{-}\right)$, sulphate $\left(\mathrm{SO}_{4}{ }^{2-}\right)$, and phosphate $\left(\mathrm{PO}_{4}{ }^{3-}\right)$, were analyzed and compared with standard permissible limits to assess the best-designated use of the river water for various purposes. The river in Delhi upstream was of better quality whereas Delhi downstream stretch was polluted as indicated by very low DO and high total dissolved solids (TDS), electric conductivity (EC), total hardness, $\mathrm{Na}^{+}, \mathrm{K}^{+}, \mathrm{Cl}^{-}, \mathrm{F}^{-}$and $\mathrm{SO}_{4}{ }^{2-}$. The differences in various parameters were statistically significant $(\mathrm{P}<0.01)$ when compared for the Delhi upstream and downstream stretches of the river, particularly in Summer. DO and TDS were found to be two important parameters, which showed strong correlation with several other parameters and hence can serve as good indices of river water quality. The river tended to recover from the pollution stress after flowing through a distance of about $80 \mathrm{~km}$ downstream Delhi.
\end{abstract}

Keywords: Yamuna, Dissolved oxygen, pollution, water quality parameter, bestdesignated use.

*Corresponding Author: (Present Address) Micro and Trace Analysis Center, Department of Chemistry, University of Antwerp, Universiteitsplein 1, B-2610, Antwerp, Belgium.e-mail: ravindra@uia.ua.ac.be Or khaiwal@yahoo.com 


\section{Introduction}

Rivers have always been the most important freshwater resources, along the banks of which our ancient civilizations have flourished and still most of the developmental activities are dependent upon them. River water finds multiple uses in every sector of development like agriculture, industry, transportation, aquaculture, public water supply etc. However, since old times, rivers have also been used for cleaning and disposal purposes. Huge loads of waste from industries, domestic sewage and agricultural practices find their way into river resulted in large scale deterioration of the water quality. The growing problem of degradation of our river ecosystem has necessitated the monitoring of water quality of various rivers all over the country to evaluate their production capacity, utility potential and to plan restorative measures ${ }^{1,2}$. The present study on water quality monitoring of river Yamuna was carried out along its course in Haryana state with a view to evaluate its ecological best designated use at different sites. There have been no systematic studies on this river in Haryana till now, although well planned monitoring has been done for the river in Delhi and Uttar Pradesh ${ }^{3-5}$.

Further, more than 70 percent of drinking water supply of Delhi is abstracted from river Yamuna ${ }^{6}$, hence it is all the more important to monitor the water quality of the river in Haryana. The permissible limits of domestic water supply for drinking water, as laid down by the United States Public Health drinking Water Standards (USPH), World Health organization ${ }^{7}$ (WHO) and Indian Standard Institutions ${ }^{8}$ (ISI) are shown in Table 1. The ISI values available for a few parameters are much higher than those for USPH. The permissible limits of the above parameter for surface water are 3-5 times higher. The 
general requirements for recreational and aesthetics, aquatic life, fish and wild life, and irrigation are described by A. K. De ${ }^{9}$ and also given in $\operatorname{ADSORBS}^{10}$.

\section{Materials and Methods}

\section{Location:}

The river Yamuna originates from Yamnotri glacier near Banderpunch peaks of Lower Himalayas $\left(38^{\circ} 59^{\circ} 78^{\circ} 27^{\circ} \mathrm{E}\right)$ in the Mussorie range at an elevation of about 6320 meter above mean sea level in the Uttarkashi district of Uttar Pradesh (U.P.). The catchment of river covers U.P, Himachal Pradesh (H.P.), Haryana, Rajasthan, Delhi and Madhya Pradesh (M.P.) with an extensive area of $3,45,843 \mathrm{~km}^{2}$ in total, out of which Haryana has a catchment area of $21,265 \mathrm{~km}^{2}$. The Yamuna is thus one of the most important rivers of the Indogangetic plains ${ }^{6}$. During summer, the snow melts and the runoff constitutes a good proportion of the flow, whereas during winter the underflows, springs, agricultural drainage and waste water inflows etc. make up the major part of the river volume.

The stretch of the Yamuna in Haryana is $~ 224 \mathrm{Km}$ from Hathnikund to Palla, after which it enters Delhi to traverse a stretch of $\sim 22 \mathrm{~km}$ and re-enters Haryana at Basantpur in Faridabad district where it covers $\sim 100 \mathrm{~km}$ before entering U.P. Thus ,for the river Yamuna, Haryana is both the upstream and downstream state with respect to Delhi. Haryana is mainly an agricultural state with 3.7 lakh hactre, out of total land area of 4.4 lakh hactare under cultivation ${ }^{11}$ with a population of 21.08 million $^{12}$. However in the past decade there has been rapid industrialization in the state. The industrial belt of Haryana is mainly situated along the north- eastern part of the state along the Yamuna. The wastes from these industries, agricultural runoff and the drains carrying municipal sewage of the cities enter in to the river and affect its water quality. 


\section{Sampling}

Sampling of the river water was done in summer (April, 1998) and during winter (Jan. -Feb., 1999). Extensive sampling was done in summer about $10 \pm 4 \mathrm{~km}$ distance covering 42 stations all along the river. On the bases of summer sampling, 16 sites were selected as representative and were repeated during winter season, which also cover the major upstream and downstream stations for important industrial complexes of the state, (Fig. 1). Grab samples of water were taken in triplicate and mixed to get composite sample for each site. Water was stored in high-grade plastic bottles of 2 L capacity. For analysis of chemical oxygen demand (COD), $\mathrm{pH}$ of the water was lowered down to 2.0 by adding $\mathrm{H}_{2} \mathrm{SO}_{4}$ and stored in glass bottles ${ }^{13}$. All the sample bottles were stored in iceboxes (i.e. below $0^{\circ} \mathrm{C}$ ) till brought to the laboratory for analysis.

\section{Water Quality Analysis}

Various physico-chemical parameters like, temperature, $\mathrm{pH}, \mathrm{EC}$, alkalinity, total hardness, total dissolved solids (TDS), $\mathrm{Ca}^{+}, \mathrm{Mg}^{2+}, \mathrm{Na}^{+}, \mathrm{K}^{+}$, chlorides $\left(\mathrm{Cl}^{-}\right)$, fluoride $\left(\mathrm{F}^{-}\right)$, Sulphate $\left(\mathrm{SO}_{4}{ }^{2-}\right)$, Nitrate $\left(\mathrm{NO}_{3}{ }^{-}\right)$, Phosphate $\left(\mathrm{PO}_{4}{ }^{3-}\right)$, Dissolved Oxygen (DO) and COD were determined following standard methods ${ }^{14}$. Temperature of the water was recorded using a thermo probe on the spot. Electrical conductivity and $\mathrm{pH}$ were also recorded on the spot using portable TDS -Scan and pH meter. DO was determiner using Winkler's method on the site itself. Calcium and magnesium were estimated using EDTA titrimetry, sodium and potassium by flame photometry, chlorides by argentometry, sulphate by nephalometry, phosphates by molybdenum -blue complex formation using spectrophotometer. Nitrate was estimated by acid treatment followed by spectrophotometry and estimation of COD was done by reflux titrimetry. 
All the reagents used for the analysis were analytical reagent grade. The quality assurance and quality procedure were also used as described in APHA ${ }^{14}$. The data were statistically analyzed for t-test and intercorrelations matrix using SPSS software package.

\section{Result and Discussion}

Out of total 42 sampling site studied in summer, 16 representative sites (Fig. 1) were sampled in winter to compare the physico-chemical characteristics of the river water during different seasons (Fig. 2-5). To differentiate the pollution load of Delhi and Haryana the river was divided into three sections:

I. (Y01-Y27) - From Hathnikund to Palla (Delhi upstream).

II. (Y-28) - Wazirabad (Delhi).

III. (Y29-Y42) - Okhla to Hassanpur (Delhi downstream).

\section{Physico-chemical characteristics}

DO in the river water showed marked variation at different stations. In the Delhi upstream stretch it ranged from 7.1 to $7.8 \mathrm{mg} / \mathrm{L}$ in summer and went up to $10.9 \mathrm{mg} / \mathrm{L}$ in winter. Lower temperature is known to favor greater dissolution of oxygen in water. DO in good quality streams is usually more than $6 \mathrm{ppm}$ to promote proper growth of fish and other aquatic organisms $^{15}$. Thus, in Delhi upstream the DO levels indicate good quality water. The DO levels fell sharply in Delhi downstream an at Okhla as well as at five subsequent stations i.e. up to an approximate downstream distance of $30 \mathrm{~km}$ from Delhi, the DO could not be detected in the water by Winkler's method. This depletion of dissolved oxygen in the river water seems to be due to the microbial decomposition organic matter that accumulates in plenty in Delhi section. High loads of organic 
pollution reaching the Yamuna from various industries and sewage through drains lead to low oxygen or even anaerobic conditions in the river water downstream to Delhi. The river is able to recover from the organic pollution stress only after covering a distance of about $35 \mathrm{~km}$ at Hasanpur probably through itself purification system, where the DO was found to be $8.5 \mathrm{mg} / \mathrm{L}$. Mass fish mortality have been reported in the river at Delhi where the DO drops sharply due to waste water outfall ${ }^{16}$.

Temperature during the sampling of summer was found to vary from 15 to $20.2^{0} \mathrm{C}$ in Delhi upstream, $29.6{ }^{\circ} \mathrm{C}$ in Delhi and $30-35{ }^{0} \mathrm{C}$ in Delhi downstream, whereas in winter the corresponding temperature, were 10.5 to $15{ }^{0} \mathrm{C}, 22{ }^{0} \mathrm{C}$ and $22{ }^{0} \mathrm{C}$ to $24{ }^{0} \mathrm{C}$ in the three sections, respectively (Fig. 2). Temperature is known to influence the $\mathrm{pH}$, alkalinity and DO concentration in the water. The $\mathrm{pH}$ of the river water varied sharply in summer and winter and also among the three sections. In Delhi upstream the $\mathrm{pH}$ ranged from $8.1-8.5$ in summer and 7.4 to 7.8 in winter. Also at Wazirabad, it was much higher in summer $(\mathrm{pH}$ 8.9) than in winter $(\mathrm{pH}$ 7.8). In Delhi downstream it varied from 7.3 to 8.8 in summer and 6.9 to 7.8 in winter. Thus the $\mathrm{pH}$ of the river water tended to be higher in summer. In general, the $\mathrm{pH}$ of Delhi upstream was more alkaline than Delhi downstream (Fig. 2). The domestic sewage and agricultural run-off are usually alkaline in nature due to presence of ammonical compounds whereas industrial waste can be acidic or alkaline. The lowering of $\mathrm{pH}$ in Delhi downstream seems to be due to greater input of waste from different type of industries and sewage of Delhi. According to Central Pollution Control Board $^{17}(\mathrm{CPCB}), 70 \%$ of the pollution in rivers is from untreated sewage. Alkaline $\mathrm{pH}$ is considered to be good for promoting high primary productivity. Thus, the upper Yamuna stretch shows more congenial conditions for primary production. 
EC of the water ranged from $0.2-0.3 \mathrm{dS} / \mathrm{m}$ in most of the Delhi upstream during summer as well as in winter. At Palla, Wazirabad and Delhi downstream the EC increased to a range of 0.6-1.2 $\mathrm{dS} / \mathrm{m}$. At Mahavat and Chandpur in Delhi downstream the EC exceeded $1.5 \mathrm{dS} / \mathrm{m}$. TDS concentration remain low in Delhi upstream upto Garh bridge (128-192mg/L), while the concentration was higher in Delhi downstream i.e. 512 to $1024 \mathrm{mg} / \mathrm{L}$ in summer and 448 to $768 \mathrm{mg} / \mathrm{L}$ in winter (Fig. 3). In Delhi upstream the drain at Palla caused an increase in TDS concentration of the river water. The TDS concentration was again found to be more in summer, which may be attributable to greater solubility of ions at higher temperature. During the dry season of summer a large proportion of the river flow in the lower Yamuna basin is reportedly derived out of the drainage from the well irrigated plans of Haryana ${ }^{10}$, which could lead to increase salinity and TDS in the lower section of the river in Haryana.

Hardness of the river water fluctuated from 140-405 mg/L during summer and 118 to $356 \mathrm{mg} / \mathrm{L}$ in winter (Fig. 3). Water with $50 \mathrm{ppm}$ of hardness is considered to be soft. Hardness of $300 \mathrm{ppm}$ is however, permissible for domestic use, whereas it should be 2 to $80 \mathrm{ppm}$ for boiler feeders, 10 to $250 \mathrm{ppm}$ for various food processing industries and $0.05 \mathrm{ppm}$ for laundry and textile industries. For agriculture, an upper limit of $150 \mathrm{ppm}$ is usually recommended. In Delhi upstream up to Jagdishpur the hardness was relatively less $(110-150 \mathrm{mg} / \mathrm{L})$ showing their suitability for drinking. The drain at Palla caused an increase in hardness $(192 \mathrm{mg} / \mathrm{L})$ and in Delhi downstream the hardness was still higher $(215-405 \mathrm{mg} / \mathrm{L})$.

Alkalinity of the river water was more in winter when the temperature was lower. During summer the alkalinity ranged from $80-250 \mathrm{mg} / \mathrm{L}$ while that in winter varied from 150-600 mg/L (Fig. 3). Alkalinity serves as a $\mathrm{pH}$ reservoir for inorganic carbon. It is 
usually taken as an index of productive potential of the water ${ }^{18}$. The higher values of alkalinity during winter indicate greater ability of the river water to support algal growth and other aquatic life in this season.

\section{Ionic composition}

The variations in cation composition of the river water viz. $\mathrm{Ca}^{+}, \mathrm{Mg}^{2+}, \mathrm{Na}^{+}$and $\mathrm{K}^{+}$ are shown in Fig. 4. $\mathrm{Ca}^{+}$, which is a major component of natural waters, comes mainly from the rocks, seepage, drainage, wastewater etc. $\mathrm{Ca}^{+}$generally varied from 50 to 70 $\mathrm{mg} / \mathrm{L}$ in Delhi upstream but increase at certain station like Drain no. 2, Palla drain and Garh bridge (90 to $108 \mathrm{mg} / \mathrm{L}$ ). Ca ion levels remained low in Delhi downstream (30-49 $\mathrm{mg} / \mathrm{L})$. The TDS content as discussed earlier, however showed the reverse trend. This indicates less solubilisation of $\mathrm{Ca}^{+}$in the Delhi downstream water. There is indication of greater precipitation of $\mathrm{Ca}^{+}$in this zone in the form of $\mathrm{CaCO}_{3}$, which is also shown by greater hardness of the downstream waters.

$\mathrm{Mg}^{2+}$ is required as an essential nutrient for plants as well as for animals and the concentration of $30 \mathrm{ppm}$ is recommended for drinking waters. The concentration of $\mathrm{Mg}^{2+}$ ions varied from 7 to $30 \mathrm{mg} / \mathrm{L}$ in Delhi upstream but the concentration was much higher (46 to $90 \mathrm{mg} / \mathrm{L}$ ) in the Delhi downstream section. The trend is the same as that for TDS, thereby indicating substantial solubilistion of $\mathrm{Mg}$ salts in downstream water. The concentration of $\mathrm{Mg}^{2+}$ was lower in winter season and only at two stations Dadsia and Chainsa, in Delhi downstream, exceeded the maximum permissible limit.

The percentage of $\mathrm{Na}^{+}$ions is often taken as important parameter deciding the suitability of water for irrigation .The $\mathrm{Na}^{+}$levels were quite low $(7-11 \mathrm{mg} / \mathrm{L})$ in most of the Delhi upstream segment. Thus, the water is suitable for drinking or irrigation. However, at Palla drain the $\mathrm{Na}^{+}$concentration increased sharply to $47 \mathrm{mg} / \mathrm{L}$ and then in 
Delhi downstream, after Okhla, the levels of $\mathrm{Na}^{+}$were elevated in the range of $88-148$ $\mathrm{mg} / \mathrm{L}$. Such higher levels of $\mathrm{Na}$ would be a potential $\mathrm{Na}^{+}$hazard for the crops if the water were used for irrigation. Presence of $\mathrm{K}^{+}$in the natural waters is very important since it is an essential nutrient element. The concentration of potassium was quite low in summer (2 to $4 \mathrm{mg} / \mathrm{L}$ ) in the upper segment, which increased up to 18 to $25 \mathrm{mg} / \mathrm{L}$ in the lower segment. The concentrations were higher during winter sampling (Fig. 5).

Excess of $\mathrm{Cl}^{-}$in inland water are usually taken as index of pollution. The sewage water and industrial effluents are rich in $\mathrm{Cl}^{-}$and hence the discharge of these wastes result in high chloride levels in fresh waters ${ }^{19}$. During summer, the $\mathrm{Cl}^{-}$in Delhi upstream of Yamuna was quite low $(5-11 \mathrm{mg} / \mathrm{L})$ indicating cleaner water. The $\mathrm{Cl}^{-}$content of the river near Palla drain increased to 40-58 $\mathrm{mg} / \mathrm{L}$ and remained high in Delhi downstream after Okhla (37 to $63 \mathrm{mg} / \mathrm{L}$ ) showing polluted state of the water obviously due to contamination by the drain waters. During winter season also the $\mathrm{Cl}^{-}$concentration did not vary much and the value ranged from 3-15 mg/L in Delhi upstream and $24-64 \mathrm{mg} / \mathrm{L}$ in Delhi downstream.

The concentration of $\mathrm{F}^{-}$in the Yamuna waters was slightly more in summer season than in winter. The concentration was highest $(1.2 \mathrm{mg} / \mathrm{L})$ at Jagdishpur. At most of the upstream stations the $\mathrm{F}^{-}$concentration ranged from $0.1-0.7 \mathrm{mg} / \mathrm{L}$ while at Delhi downstream stations the levels were higher $(0.7$ to $0.9 \mathrm{mg} / \mathrm{L})$, but tended to remain within permissible limits. $\mathrm{SO}_{4}{ }^{2-}$ concentration in the river varied from 14 to $63 \mathrm{mg} / \mathrm{L}$ in Delhi upstream and increased from 70 to $80 \mathrm{mg} / \mathrm{L}$ in Delhi downstream. The waste water from tanneries, paper mills and textile mills usually contribute to the $\mathrm{SO}_{4}{ }^{2-}$ in natural water along with some agricultural runoff containing leachates of gypsum which was evidently the case in Delhi downstream. The concentration of $\mathrm{SO}_{4}{ }^{2-}$ was much lower in winter. 
$\mathrm{NO}_{3}{ }^{-}$in river water promotes high primary productivity and excess of $\mathrm{NO}_{3}{ }^{-}$in surface water is taken as a warning for algal blooms. However, the $\mathrm{NO}_{3}{ }^{-}$levels were quite low, varying from 0.5 to $2.3 \mathrm{mg} / \mathrm{L}$ during both the seasons with the exception of relatively higher values of 5-9 mg/L in Mohana and Hasanpur during winter. These high values seem to be due to local run-off from the adjacent crop field in these areas where the farmers had used Nitrogen-fertilizers. Thus, there was no indication of $\mathrm{NO}_{3}{ }^{-}$pollution in Yamuna waters in Haryana, in general.

$\mathrm{PO}_{4}{ }^{3-}$ are present in natural waters as soluble phosphates and organic phosphates. Concentration of available $\mathrm{PO}_{4}{ }^{3-}$ was low in the upstream water ranging from 0.02 to 0.26 $\mathrm{mg} / \mathrm{L}$ in Delhi upstream. However, the $\mathrm{PO}_{4}{ }^{3-}$ increased from $0.8 \mathrm{mg} / \mathrm{L}$ in Delhi downstream, a concentration high enough to cause eutrophication. The phosphate levels increased further during winter ranging from 0.12 to $2.8 \mathrm{mg} / \mathrm{L}$ in the river with higher levels in the downstream stretch. Agricultural runoff containing phosphate fertilizers as well as waste water containing detergents etc. tend to increase $\mathrm{PO}_{4}{ }^{3-}$ pollution in the Delhi downstream water.

The COD is a measure of oxygen equivalent to the organic matter content of the water susceptible to oxidation by a strong chemical oxidant and thus is an index of organic pollution in the river. The COD level in the river water Hathnikund was 9.8 mg/L. Although Yamunanagar produces significant COD loads of 9,7092 kg/day ${ }^{20}$, yet the COD level in Yamunanagar downstream was not so high $(10.5 \mathrm{mg} / \mathrm{L})$. In fact, the industrial as well as domestic wastes of Yamunanagar are mostly discharged into Western Yamuna Canal. Similarly, the high pollution load of Panipat (1238 kg/day) and Sonipat (6496 kg/day) mostly enter into the canal system and only after traversing several tens of kilometers enter into the river. By that time, there is substantial recovery of the 
canal water. COD levels in the river in Delhi downstream stretch were determined and reported in Table 2 which is the most polluted section of the river in Haryana and yet no study has been conducted till now on it. In the upstream stretch the COD has earlier been reported to $10.3 \pm 0.05 \mathrm{mg} / \mathrm{L}$ at Palla and $39.3 \pm 1.1 \mathrm{mg} / \mathrm{L}$ at $\mathrm{Okhla}^{21}$. The COD level in Yamuna waters in Delhi downstream were 14.4 to $17.6 \mathrm{mg} / \mathrm{L}$ from Basantpur to Dadsiya. At Khedawali, the COD was very high $(28.8 \mathrm{mg} / \mathrm{L})$ and then decreased in the downstream station from 9.6 to $6.5 \mathrm{mg} / \mathrm{L}$ as the river passed from Ghurason to Hasanpura, the entry point to U.P. Thus, in this section also the river system recovered from the high pollution load before entering U.P. An earlier report showed 9 to $27 \mathrm{mg} / \mathrm{L}$ of COD at a few stations in Delhi upstream section (Haryana) and 23 to $29 \mathrm{mg} / \mathrm{L}$ in Delhi downstream through U.P. ${ }^{6}$. The present study also showed comparable values of COD in the upper segment. In the Delhi downstream through Haryana the COD was however, relatively less in the Yamuna than that in the downstream which passed through U.P. The COD levels of Yamuna was found to be much less when compared to that in river Damodar, which showed 23 to 92 ppm of $\mathrm{COD}^{22}$.

The variation in various physico-chemical characteristics of the river water in Delhi upstream and downstream stretches were tested for significance of difference using t-test. During summer all the parameter values except $\mathrm{pH}$ differed significantly $(\mathrm{p}<0.01)$ in the two stretches. This showed that river water quality was largely affected by various waste inputs in Delhi segment, which caused the significant variations in water quality in Delhi. However some of the parameters like DO, alkalinity, $\mathrm{Ca}^{+}$, hardness etc. tended to recover after covering a distance of about $80 \mathrm{~km}$ at Hasanpur (Y-38). Other like EC, TDS, $\mathrm{Na}^{+}, \mathrm{K}^{+}, \mathrm{Mg}^{2+}, \mathrm{Cl}^{-}, \mathrm{F}^{-}, \mathrm{SO}_{4}{ }^{2-}, \mathrm{NO}_{3}{ }^{-}$and $\mathrm{PO}_{4}{ }^{3-}$ remained much higher in concentration of the river right up to U.P. border. 


\section{Inter-relationships}

Table 3 presents the correlation matrix between various parameters. Most of the parameters were found to bear statistically significant correlation with each other indicating close association of these parameters with each other. The $\mathrm{pH}$ and $\mathrm{DO}$ of the water however, showed a highly positive correlation $(r=0.7972, \mathrm{df}=40, \mathrm{p}<0.01)$. Both the parameters are indicators of good quality water indicating the various favorable conditions for high primary and secondary production. TDS and EC also had a strong correlation with a number of parameters like $\mathrm{Cl}^{-}(\mathrm{r}=0.9137)$, hardness $(\mathrm{r}=0.9669), \mathrm{Mg}^{2+}$ $(\mathrm{r}=0.9634), \mathrm{Na}^{+}(\mathrm{r}=0.9915), \mathrm{K}^{+}(\mathrm{r}=0.9724)$, and $\mathrm{SO}_{4}{ }^{2-}(\mathrm{r}=0.8374)$. Thus, a single parameter of TDS can give a reasonably good indication of a number of related parameters.

$\mathrm{Na}^{+}$is well correlated with $\mathrm{Cl}^{-}$and $\mathrm{SO}_{4}{ }^{2-}$. However, $\mathrm{Ca}^{+}$bears a significant negative correlation with $\mathrm{EC}, \mathrm{TDS}, \mathrm{SO}_{4}{ }^{2-}, \mathrm{PO}_{4}{ }^{3-}$ and other cations. This indicates the presence of calcium in the water in less soluble forms, more likely in the form of carbonates, which is also indicated by the high values of hardness in the river water.

Dissolved oxygen showed significantly negative correlation with all the parameters except $\mathrm{pH}$ with which it had a positive correlation. Only $\mathrm{Ca}^{+}$and $\mathrm{Mg}^{2+} \mathrm{did}$ not bear any significant with DO Thus, DO can serve as a single useful index of water quality of the river because with increase in the value of most of these parameters, the DO decreases.

\section{Ecological Best Designated Use}

Some ecological parameters were used to decide the best use of the River Yamuna flowing in Haryana like irrigation, industrial processing and cooling, drinking water 
resource, outdoor bathing, propagation of wildlife, navigation, fishery, recreation and controlled waste water disposal. Base on the parameter value of $\mathrm{pH}, \mathrm{EC}, \mathrm{TDS}, \mathrm{Na}, \mathrm{NO}_{3}$, $\mathrm{SO}_{4}, \mathrm{PO}_{4}$ and $\mathrm{DO}$ and the maximum permissible limits for these parameters it may be concluded that the stretch of Yamuna from Hathnikund to Palla is suitable for drinking, bathing, wildlife fisheries, recreation, irrigation and industrial cooling following water quality criteria for various designated best use as outlined by $\operatorname{ADSORBS}^{10}$.

However, in the Delhi downstream the hardness was quite high, hence could not be prescribed for boiler feeders, food processing industries, textiles and laundry. The high $\mathrm{SO}_{4}$ levels have also rendered the water unsuitable for dairy, textile and sugar mills. high chlorides levels and low DO levels in this section have made the water unfit for drinking, bathing or wildlife fisheries etc. However, the water could be used on limited scale for irrigation and industrial cooling.

\section{Acknowledgement}

Financial Assistance from Environment Department, Government of Haryana, Chandigarh (India), for the research project "Monitoring of the river water quality of major rivers of Haryana," of which the present study forms a part, is gratefully acknowledged. We are also thankful to Dr. V.K. Garg, Mr. Mukul Bishnoi and Er. (Mrs) Suman Mor for timely help. 


\section{References}

1. M.O. Datar, R.P. Vashistha,. Indian Journal of Environmental Protection, 1992, $12,577$.

2. $\quad$ N.K. Das, R. K. Sinha, India Environment and Ecology, 1993, 11, 829.

3. R.C. Trivedi, S.D. Makhijani, P.M. Ansari, I.S. Kanjora, Pollution of River Yamuna in Delhi and plan for its improvement- Proceedings of National Seminar Pollution Control \& Environment management. Nagpur, 17-18 March, 1985, pp. $55-61$.

4. A.W. Israili, M.S. Ahmad, Ind. Environ. Health, 1993, 34, 63.

5. A. Aggarwal, Homicide by pesticides, Center for Science and Environment, New Delhi, 1997, pp. 47-98.

6 Central Pollution Control Board (CPCB), Report on water quality monitoring of Yamuna river, Delhi, 1996.

7. World Health organization (WHO), WHO Handbook, Genawa, 1986.

8. Indian Standard Institution (ISI), Indian standard specification for drinking water, $15,16500,1983$.

9. A. K. De. Environmental Chemistry, New Age International Publishers, New Delhi, $4^{\text {th }}$ edn., 2000.

10. ADSORBS, The Ganga Basin, Central Board for the prevention and control of water pollution, New Delhi, 1982. ADSORBS/2/1980-81.

11. Department of Agriculture (D.O.A.). Haryana. Agricultural statistics of Haryana, Department of Agriculture, Haryana, Chandigarh, 1996, pp.12.

12. Census of India 2001, (www.censusindia.net/results/index.html)

13. M.C. Rand, A.E. Greenberg, M.J. Taras. Standard Method for the examination of Water and Waste Water, American Public Health association, Washington DC, USA, $14^{\text {th }}$ edn., p.p. 42-43, 1976.

14. APHA-AWWA-WPCF, Standard Methods for the Examination of Water and Wastewater, American Public Health Association, Washington, DC, 15th edn., 1994.

15. T. G. Miller. Living in the Environment, Principles, connections and solutions, $8^{\text {th }}$ edn. Wadsworth Publ. Co., California, 1994.

16. D.S. Bhargava, Environ. Pollut., 1985, 37, 355. 
17. Central Pollution Control Board (CPCB), Water quality status of Yamuna River, Parivesh Bhawan, Delhi, 1999-2000.

18. S.E. Manahan, Environmental Chemistry. Lewis Public. CRC Press, USA, 1994.

19. S.M. Hasalam. River Pollution- An Ecological Perspective, Belhaven Press, Great Britain, 1991.

20. IWACO, Risk Assessment of Yamuna River: Water quality monitoring stations in India. Phase II , Government of India and Goverment of Netherlands, Rotterdam, 1996, pp. 33.

21. H.R. Sharma, D. Chhetry, A. Kaushik, R.C. Trivedi, J. Environ. Pollut., 2000, 7, 185-188.

22. A.K. De, Studies of Environment Pollution in Damodar River. Final report for Directorate of Environment (DOE) Project: Growth of water pollution in AsansolDurgapur Industrial belt and its impact on water quality of Damodar River, 1982, New Delhi. 
Table 1: Drinking water quality standards as recommende by USPH, WHO and ISI.

\begin{tabular}{|l|l|l|l|}
\hline Parameter & USPH Standard & WHO standards & $\begin{array}{l}\text { ISI Standard } \\
\text { (IS: 2296-1963) }\end{array}$ \\
\hline Colour & Colourless & - & - \\
Odour & Odourless & - & - \\
Taste & Tasteless & - & - \\
pH & $6.0-8.5$ & $6.5-9.2$ & $6.0-9.0$ \\
D.O. & $4.0-6.0$ & - & 3.0 \\
T.D.S. & 500 & 500 & - \\
Cl & 250 & 500 & 600 \\
SO4 & 250 & 200 & 1000 \\
NO3 & $<10$ & 45 & - \\
F & 1.5 & 0.5 & 3.0 \\
PO4 & 0.1 & - & - \\
Ca & 100 & 100 & - \\
Mg & 30 & 150 & - \\
C.O.D. & 4.0 & 10 & - \\
\hline
\end{tabular}

Except $\mathrm{pH}$ all unit are in $\mathrm{mg} / \mathrm{L}$. 
Table 2: Chemical oxygen demand (COD) of river Yamuna in Delhi downstream stretch in Haryana.

\begin{tabular}{|l|l|}
\hline Sampling Sites & COD $(\mathbf{m g} / \mathbf{L})$ \\
\hline & 14.4 \\
Basantpur (Y-30) & 17.6 \\
Dadsiya (Y-31) & 28.8 \\
Khidawali (Y-32) & 15.4 \\
Mahavat (Y-33) & 6.4 \\
Ghjursan (Y-34) & 9.6 \\
Chandanpur (Y-35) & 8.0 \\
Chainsa (Y-36) & 9.9 \\
Mohana (Y-37) & 4.8 \\
Hassanpur (Y-38) & 8.0 \\
Gurwari (Y-39) & 8.0 \\
Rahipur (Y-40) & 4.8 \\
Kushak (Y-41) & 6.5 \\
Hasanpura (Y-42) & \\
\hline
\end{tabular}


Table 3: Correlation matrix of various water quality parameters.

\begin{tabular}{|c|c|c|c|c|c|c|c|c|c|c|c|c|c|c|c|c|}
\hline Temn & Temp. & $\mathrm{pH}$ & EC & TDS & $\mathrm{Cl}$ & ALK. & $\mathrm{TH}$ & $\mathrm{Ca}$ & $\underset{86^{* * *}}{\mathrm{Mg}}$ & $\mathrm{Na}$ & $\mathrm{K}$ & $\mathrm{F}$ & $\mathrm{NO}_{5} \mathrm{~N}_{3}$ & $\mathrm{SO}_{4}$ & $\mathrm{PO}_{4}$ & $\begin{array}{l}\text { DO } \\
-.56^{* * *+}\end{array}$ \\
\hline $\mathrm{pH}$ & & $\begin{array}{l}. .43 \\
1.00\end{array}$ & $-.46^{* * *}$ & $\begin{array}{l}.09 \\
-.46^{* * * *}\end{array}$ & $-.33^{* *}$ & $\begin{array}{l}.50 \\
-.34^{*}\end{array}$ & $\begin{array}{l}.05 \\
-.50^{2=*}\end{array}$ & $.23^{\mathrm{NS}}$ & $-48^{n=t}$ & $-.42^{* *}$ & $-42^{* *}$ & $-.15^{\mathrm{NS}}$ & $-.06^{\mathrm{NS}}$ & $.27^{\mathrm{NS}}$ & $-45^{=+*}$ & $.80^{* * *}$ \\
\hline EC & & & 1.00 & $1.00^{* * * *}$ & $.91^{* * *}$ & $.78^{* * *}$ & $.97^{* * * *}$ & $-.56^{* * *}$ & $.96^{* * *}$ & $.99^{* * * *}$ & $.97^{* * * *}$ & $.56^{* * *}$ & $.59^{* * *}$ & $.84^{* * *}$ & $.72^{* * *}$ & $-.63^{* * *}$ \\
\hline TDS & & & & 1.00 & $.91^{* * *}$ & $.78^{* * *}$ & $.97^{* * * *}$ & $-.56^{* * *}$ & $.96^{* * *}$ & $.99^{* * *}$ & $.97^{* * * *}$ & $.56^{* * *}$ & $.59^{* * *}$ & $.84^{* * *}$ & $.72^{* * *}$ & $-.63^{* * *}$ \\
\hline CL & & & & & 1.00 & $.80^{* * *}$ & $.85^{* * *}$ & $-.34^{* *}$ & $-.82^{* * *}$ & $.91^{* * * *}$ & $.85^{* * *}$ & $.55^{* * *}$ & $.65^{* * *}$ & $.83^{* * *}$ & $.64^{* * *}$ & $-.57^{* *=}$ \\
\hline ALK. & & & & & & 1.00 & $.75^{* * *}$ & $-.22^{\mathrm{Ns}}$ & $.71^{* * *}$ & $.77^{* * * *}$ & $.76^{* * *}$ & $.49^{* * *}$ & $.74^{* * *}$ & $.59^{* * *}$ & $.58^{* * *}$ & $-.57^{* *=}$ \\
\hline TH & & & & & & & 1.00 & $.53^{*+*}$ & $.99^{* * *}$ & $.95^{* * *}$ & $.93^{* * *}$ & $.49^{* * *}$ & $.50^{* * *}$ & $.76^{* * *}$ & $.69^{* * * *}$ & $-.61^{* * *}$ \\
\hline $\mathrm{Ca}$ & & & & & & & & 1.00 & $-.66^{* * *}$ & $-.57^{* * *}$ & $-.61^{* * z}$ & $-.20^{\mathrm{NS}}$ & $-.02^{\mathrm{NS}}$ & $-.53^{* * s}$ & $-.41^{* * *}$ & $.22^{\mathrm{NS}}$ \\
\hline $\mathrm{Mg}$ & & & & & & & & & 1.00 & $.063^{\mathrm{NS}}$ & $-.07^{\mathrm{NS}}$ & $-.18^{\mathrm{NS}}$ & $.05^{\mathrm{NS}}$ & $.02^{\mathrm{NS}}$ & $-.07^{\mathrm{NS}}$ & $-.08^{\mathrm{Ns}}$ \\
\hline $\mathrm{Na}$ & & & & & & & & & & 1.00 & $.98^{* * *}$ & $.59^{* * *}$ & $.61^{* * *}$ & $.86^{* * *}$ & $.71^{* * *}$ & $-.60^{* * *}$ \\
\hline K & & & & & & & & & & & 1.00 & $.59^{* * * *}$ & $.65^{* * *}$ & $.87^{* * * *}$ & $.72^{* * *}$ & $-.60^{* * *}$ \\
\hline $\mathrm{F}$ & & & & & & & & & & & & $1.00^{*=*}$ & $.46^{* * *}$ & $.54^{* * * *}$ & $.46^{* * *}$ & $-.36^{* *}$ \\
\hline $\mathrm{NO}_{3}$ & & & & & & & & & & & & & 1.00 & $.56^{* * * *}$ & $.49^{=* * *}$ & $-.40^{* *}$ \\
\hline $\mathrm{PO}_{4}$ & & & & & & & & & & & & & & 1.00 & $.55^{* * *}$ & $-.53^{* * *}$ \\
\hline $\mathrm{SO}_{4}$ & & & & & & & & & & & & & & & 1.00 & $-.50^{* * s}$ \\
\hline DO & & & & & & & & & & & & & & & & 1.00 \\
\hline
\end{tabular}




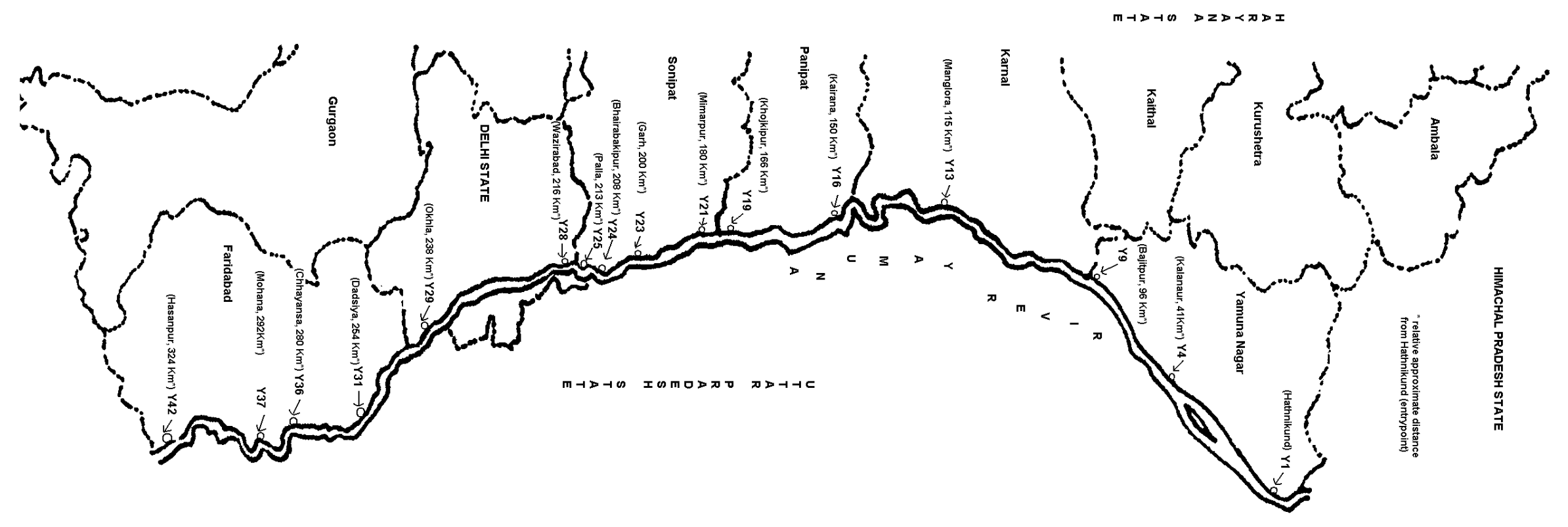

Figure 1: Representative sampling stations along the route of river Yamuna in Haryana. 

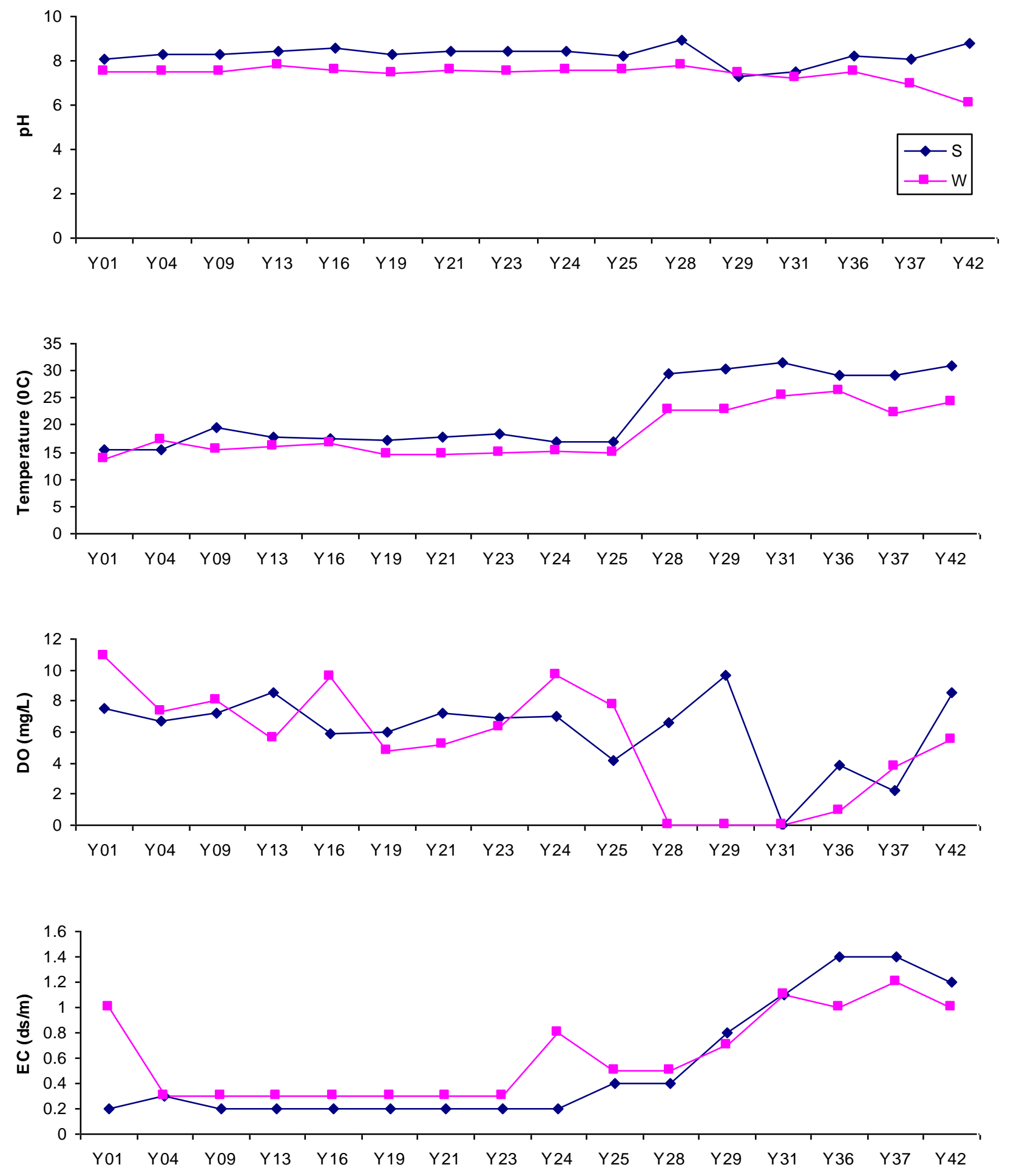

\section{Sampling Stations}

Figure 2: Seasonal variation in $\mathrm{pH}$, temperature, $\mathrm{DO}$ and $\mathrm{EC}$ concentration in the water samples of river Yamuna flowing in Haryana. ( $\mathrm{S}=\mathrm{Summer}, \mathrm{W}=$ Winter). 

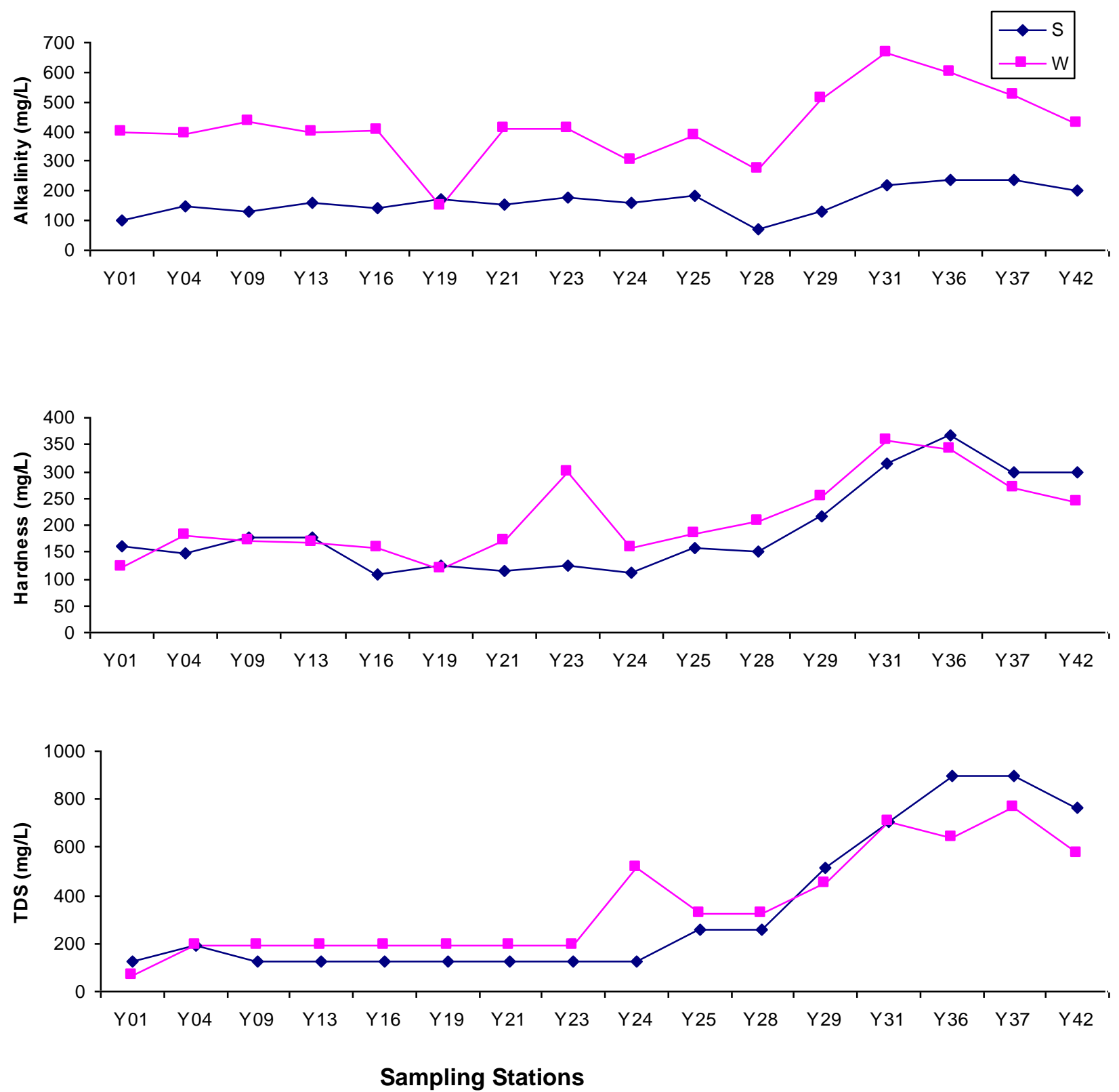

Figure 3: Seasonal variation in alkalinity, total hardness and total dissolved solids (TDS) concentration in the water samples of river Yamuna flowing in Haryana. $(\mathrm{S}=\mathrm{Summer}$, $\mathrm{W}=$ Winter). 

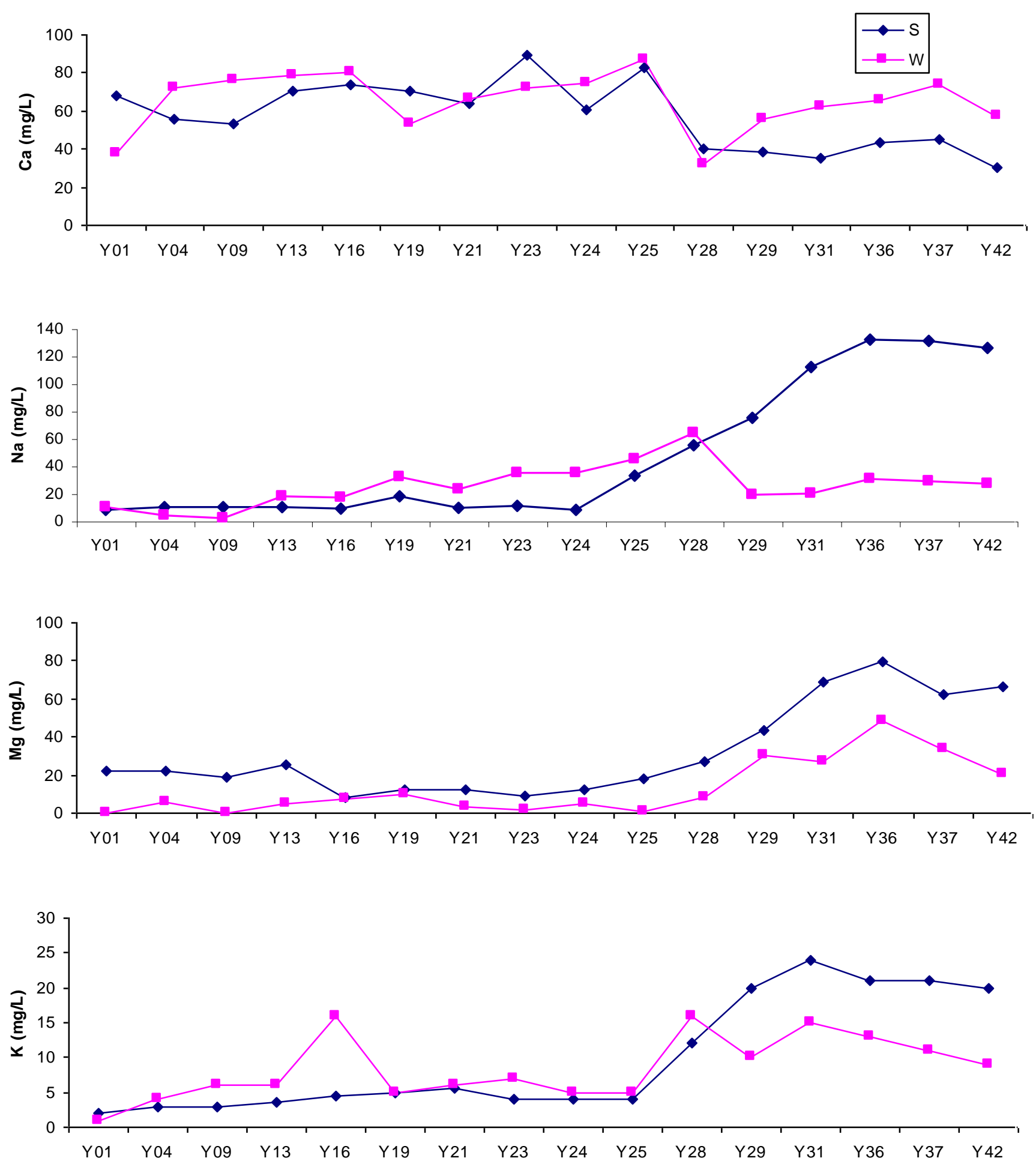

\section{Sampling stations}

Figure 4: Seasonal variation in $\mathrm{Ca}, \mathrm{Mg}, \mathrm{Na}$ and $\mathrm{K}$ concentration in the water samples of river Yamuna flowing in Haryana. ( $\mathrm{S}=$ Summer, $\mathrm{W}=$ Winter). 

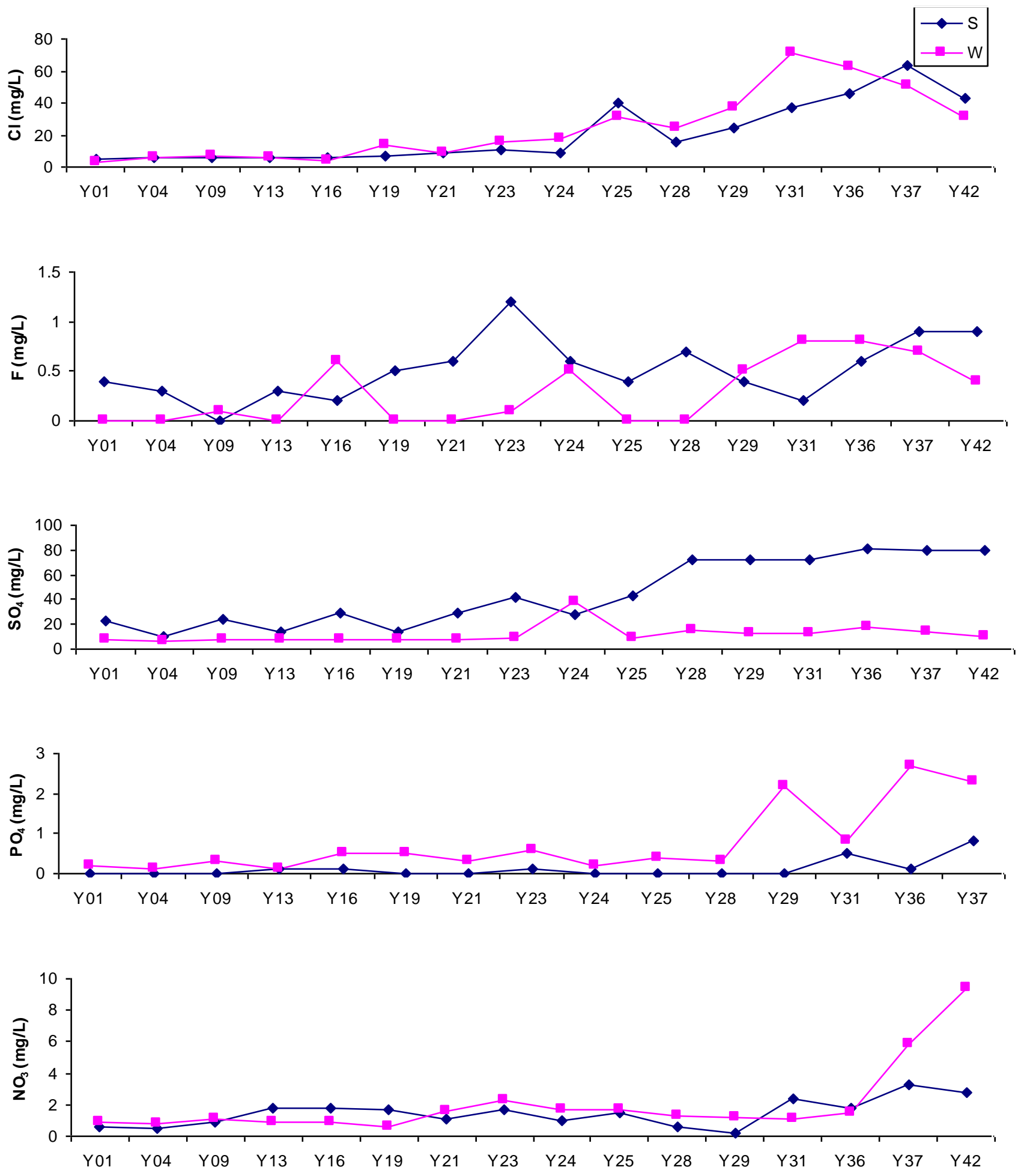

\section{Sampling stations}

Figure 5: Seasonal variation in $\mathrm{Cl}, \mathrm{F}, \mathrm{SO}_{4}, \mathrm{PO}_{4}$, and $\mathrm{NO}_{3}$ concentration in the water samples of river Yamuna flowing in Haryana. ( $\mathrm{S}=$ Summer, $\mathrm{W}=$ Winter). 